\title{
$\therefore$ \\ Differentially Expressed Proteins from Roots of Healthy and Diseased Piper nigrum
}

\section{IJCRR}

Section: Healthcare

ISI Impact Factor

(2019-20): 1.628

IC Value (2019): 90.81

$\operatorname{SJIF}(2020)=7.893$

(c) (7) (8)

Copyright@IJCRR

\section{Hussain $\mathrm{H}^{1}$, Hamdin $\mathrm{NE}^{1}$, Chong NFM${ }^{1}$, Husaini $\mathrm{AA}^{2}$, Lihan $\mathrm{S}^{3}$}

'Centre for Sago Research (CoSAR), Faculty of Resource Science and Technology, Universiti Malaysia Sarawak, 94300 Kota Samarahan,

Sarawak, Malaysia; 'Faculty of Resource Science and Technology, Universiti Malaysia Sarawak, 94300 Kota Samarahan, Sarawak, Malaysia; ${ }^{3}$ Institute of Biodiversity and Environmental Conservation, Universiti Malaysia Sarawak 94300 Kota Samarahan, Sarawak, Malaysia.

\section{ABSTRACT}

Introduction: Diseased Piper nigrum plants have affected pepper berry production in Sarawak farms, contributing to the economic loss for farmers that depend on this species for their income.

Objective: This study was performed to analyse the protein profiles of healthy and diseased $P$. nigrum roots and to identify differentially expressed proteins.

Methods: Two methods of protein extraction were compared, and the extracted proteins were quantified through two quantitative assays: the Bradford and BCA assays. The Phenol/SDS extraction method was significantly better compared to the phenol method.

Results: The SDS-PAGE analysis revealed two differently expressed unique proteins bands with the molecular size of approximately $20 \mathrm{kDa}$ and $12.5 \mathrm{kDa}$ present in the sample of diseased plants. These differentially expressed proteins are likely to be pathogenesis-related (PR) proteins which are produced as a response to infection.

Conclusion: These PR proteins can potentially be used as markers or be developed further to allow plants to gain systemic resistance against diseases.

Key Words: BCA assays, Pathogenesis-related proteins, Phenol extraction, Piper nigrum, Proteomics

\section{INTRODUCTION}

Piper nigrum plant known as black pepper is a type of woody perennial climber with dilated or swollen nodes and stipules. ${ }^{1}$ Peppers from Indian origins are widely grown in pepper producing countries such as Thailand and Malaysia because of high quality and yield. The pepper berry has been used as a spice and seasoning due to its pungent flavour and aromatic scent. In addition to the main usage as spice and seasoning, different parts of the plant have been used for the extraction of the secondary metabolites. These metabolites were used in drugs, preservative, insecticidal and larvicidal control agents. ${ }^{2}$ For example, studies have shown that $P$. nigrum affects the digestive system, where piperine increases the production of saliva and gastric secretions.,

Through a proteomic study of $P$. nigrum roots, this study aims to identify proteins which are expressed as a response towards disease and infection. The previous study from leaves has revealed the role of different pathogenesis-related (PR) proteins and enzymes in the disease reaction of black pepper concerning Phytophthora capsici foot rot infection. ${ }^{5}$ Nowadays, advancements in proteomic studies have allowed the quantitative and qualitative separation of complex protein mixtures, which makes it possible to monitor dynamic protein expression in plant growth and metabolism by using two-dimensional electrophoresis (2-DE) and mass spectrometry analysis. ${ }^{6-9}$

The study hypothesis is that there are differently expressed proteins in $P$. nigrum plants when compared between the healthy and foot rot diseased roots caused by Phytophthora. In this study, two different extraction protocols were evaluated. Furthermore, two protein quantification methods, the Bradford assay and Bicinchoninic acid assay were compared. Lastly, the protein profiles of the healthy and diseased samples were compared to identify any differentially expressed proteins.

\section{Corresponding Author:}

Hussain H, Centre for Sago Research (CoSAR), Faculty of Resource Science and Technology, Universiti Malaysia Sarawak 94300, Kota Samarahan, Sarawak, Malaysia; Tel: +60 82 583012; Fax: 6082 583160; Email: hhasnain@unimas.my

ISSN: 2231-2196 (Print)

Received: 10.09 .2020
ISSN: 0975-5241 (Online)

Revised: 16.10 .2020
Accepted: 18.11 .2020
Published: 23.02 .2021 


\section{MATERIALS AND METHODS}

\section{Study site}

The healthy and diseased roots of the P. nigrum samples were collected in Serian, Sarawak, Malaysia. The samples of healthy $P$. nigrum plants were identified by the plants producing green rounded fruit berries and healthy green leaves. Meanwhile, the diseased samples were collected from the plants that showed diseased symptoms like visibly stunted growth and some rotting on the plant. Three replicates of healthy and diseased plants were collected for sample analysis.

\section{Plant Materials}

The roots were washed and cleaned with running water to remove any attached soil. Then, the roots were rinsed with distilled water, followed by $70 \%$ ethanol to remove any remaining contamination. The samples were stored at $-80{ }^{\circ} \mathrm{C}$ until used. The roots were finely powdered by grinding with liquid nitrogen using a mortar and pestle. Proteins were extracted from the healthy and diseased roots using two different extraction methods which were the phenol extraction and the phenol/SDS extraction method, with three replicates, respectively.

\section{Protein Extraction Methods}

\section{Phenol protein extraction}

This phenol extraction method is based on Faurobert et al. ${ }^{10}$ with modification as described. Firstly, $0.4 \mathrm{~g}$ of ground tissue was suspended in $0.8 \mathrm{ml}$ of extraction buffer $(500 \mathrm{mM}$ Tris$\mathrm{HCl}, \mathrm{pH}$ 8.0, $50 \mathrm{mM}$ EDTA, $700 \mathrm{mM}$ sucrose, $100 \mathrm{mM} \mathrm{KCl}$, $2 \% \beta$-mercaptoethanol and $1 \mathrm{mM}$ phenylmethylsulfonyl fluoride) and vortexed. Then, it was incubated by shaking for $10 \mathrm{~min}$ on ice. After that, an equal volume of Tris-buffered phenol was added to the mixture, vortexed and incubated on a shaker for another $10 \mathrm{~min}$ at room temperature. The sample was centrifuged at $16000 \mathrm{Xg}$ for $10 \mathrm{~min}$ at $4{ }^{\circ} \mathrm{C}$. The upper phenolic phase was transferred into a new tube. Then, this phenolic phase was back-extracted with $0.8 \mathrm{ml}$ of extraction buffer. The sample was vortexed and shaken at room temperature for $10 \mathrm{~min}$. Centrifugation was repeated at 16000 $\mathrm{X}$ g for $10 \mathrm{~min}$ at $4{ }^{\circ} \mathrm{C}$. The upper phenolic phase was transferred into a new tube. Next, three volumes of cold $0.1 \mathrm{M}$ ammonium acetate in methanol was added as a precipitation solution. The tube was shaken by inverting, and the sample was incubated overnight at $-20^{\circ} \mathrm{C}$. The protein was pelleted by centrifugation at $16000 \mathrm{Xg}$ for $10 \mathrm{~min}$ at $4{ }^{\circ} \mathrm{C}$. The pellet was washed once with cold precipitation solution and once with cold $80 \%$ acetone. Finally, the pellet was air-dried and stored at $-20{ }^{\circ} \mathrm{C}$.

\section{Phenol/SDS protein extraction}

The phenol/SDS extraction method is based on Rodrigues et al. ${ }^{11}$ with modification as described. Firstly, $0.4 \mathrm{~g}$ of ground tissue was suspended in $0.8 \mathrm{ml}$ of Tris-buffered phenol, $\mathrm{pH}$ 8.0 and $0.8 \mathrm{ml}$ of SDS buffer $(0.1 \mathrm{M}$ Tris- $\mathrm{HCl}, \mathrm{pH} 8.0,2 \%$ SDS, $5 \% \beta$ - mercaptoethanol, $30 \%$ sucrose, and $1 \mathrm{mM}$ phenylmethylsulfonyl fluoride). The mixture was vigorously vortexed and incubated for $10 \mathrm{~min}$. Then, the mixture was centrifuged at $16,000 \mathrm{Xg}$ for $5 \mathrm{~min}$ at $4{ }^{\circ} \mathrm{C}$. The upper phenolic phase was transferred into a new tube. Three volumes of cold $0.1 \mathrm{M}$ ammonium acetate in methanol were then added to the tube. The tube was shaken by inverting, and the sample was incubated overnight at $-20{ }^{\circ} \mathrm{C}$. The protein was pelleted by centrifugation at $16,000 \mathrm{~g}$ for $5 \mathrm{~min}$ at $4{ }^{\circ} \mathrm{C}$ and washed in the same way as the phenol extraction method; once with cold $0.1 \mathrm{M}$ ammonium acetate in methanol and once with cold $80 \%$ acetone. Finally, the pellet was air-dried and stored at $-20^{\circ} \mathrm{C}$.

\section{Protein Quantification}

\section{Bradford assay}

The protocol was adapted from Bradford ${ }^{12}$ and Stoscheck ${ }^{13}$. The protein standards using bovine serum albumin (BSA) were prepared with different concentrations $(0.2,0.4,0.6$, 0.8 and $1.0 \mathrm{mg} / \mathrm{ml}$ ). Each of the volumes was pipetted into a $1.5 \mathrm{ml}$ Eppendorf tube and the volume was adjusted to $20 \mu \mathrm{l}$ by adding a buffer solution, $0.05 \mathrm{M}$ Tris-HCl. On the other hand, the sample proteins were prepared with a range of 1 , 1:1, 1:9 dilutions with a total of $20 \mu \mathrm{l}$ and pipetted into a 1.5 $\mathrm{ml}$ Eppendorf tube. After that, all of the tubes were added with $1 \mathrm{ml}$ of Bradford reagent including the blank tube (20 $\mu 10.05 \mathrm{M}$ Tris- $\mathrm{HCl}$ ), vortexed and incubated at room temperature for $5 \mathrm{~min}$. A spectrophotometer (OPTIMA SP-300) was used to analyse the BSA standard solution and protein samples at the absorbance of $595 \mathrm{~nm}$.

\section{Bicinchoninic acid (BCA) assay}

The BSA protein standards and samples were prepared as described for the Bradford assay. ${ }^{14,15} 1 \mathrm{ml}$ of standard working solution was added to each sample and mixed using a vortex. The samples were then incubated for $30 \mathrm{~min}$ at $60{ }^{\circ} \mathrm{C}$. Next, the samples were cooled before measurement using a spectrophotometer (OPTIMA SP-300) at $562 \mathrm{~nm}$.

\section{SDS PAGE}

Protein extracts were separated using SDS-PAGE according to the protocol from Laemmli ${ }^{16}$. The gels were stained with Coomassie Brilliant Blue R (CBB-R) staining solution. The gels were then destained with $10 \%$ acetic acid for 2 hours.

\section{Image analysis and MALDI-ToF/ToF mass spectrometry}

The gel image was analysed using ImageJ software and the selected protein bands were subjected to MALDI-ToF/ ToF analysis for protein identification. The gel bands excised from 1-D gels were de-stained and proceeded with in-gel trypsin digestion based on the in-house method developed 
from Shevchenko et al. ${ }^{17,18}$ The extracted peptides were analysed using MALDI ToF/ToF 5800 mass spectrometer (Sciex, Framingham, USA). Spectra obtained were analysed to identify the proteins of interest using Mascot search engine. ${ }^{19}$

\section{RESULTS}

\section{Protein quantification for Piper nigrum}

Quantification of protein was done using two assays which were Bradford assay and BCA assay. Table 1 shows the average concentration of proteins from the roots of healthy and diseased P. nigrum, as quantified using the Bradford and BCA assays.

\section{Protein profiles using SDS-PAGE}

From the results of SDS-PAGE stained using Coomassie Brilliant Blue R (CBB-R), there were some differences observed between the protein profiles of healthy and diseased $P$. nigrum roots, where two additional protein bands were present in diseased roots. Diseased roots (Figure 1; lane $b$ and d) showed two distinct bands estimated at $\sim 20 \mathrm{kDa}$ and $\sim 12.5 \mathrm{kDa}$ respectively. These bands were only faintly observed in healthy roots (Figure 1; lane a and c), compared to other protein bands in both healthy and diseased samples that were of equal intensity. Analysis of variance (ANOVA) for protein concentration was conducted to identify any differences in protein concentration between the extracted samples. From Table 2 and Table 3, the F-values were smaller than F-critical, $2.175<4.066$ and $0.742<4.066$ respectively, to determine significant differences of protein concentration between the healthy and diseased samples from the two different extraction methods.

\section{Identification of differentially expressed pro- teins by MALDI-ToF/ToF MS}

The differentially expressed proteins by MALDI-ToF/ ToF mass spectrometry showed Mascot scores for the Protein Band 1 at 44 and 30, indicating close but not exact or matched identity to the identified proteins (Table 4). The Protein Band 1 showed peptide with the highest score of 44 matched a mannose-binding lectin (MBL) or the score of 30 to match with agglutinin protein. Result of the Protein Band 2 analysis showed low hit Mascot scores in the protein database (Table 4). The peptide with the highest score-matched and AAA-type ATPase family protein, as well as a hypothetical protein OsI_11535.

\section{DISCUSSION}

\section{Analysis of protein quantification for Piper nigrum}

The phenol/SDS extraction method yielded a higher protein concentration than the phenol extraction method. Compared to the original phenol/SDS extraction method ${ }^{20}$, the modified phenol/SDS extraction method by Rodrigues et al. ${ }^{11}$ avoided the preliminary washing step. It was suitable both for removing interfering compounds and minimising protein degradation in extracts.

The analysis of variance (ANOVA) for protein concentration to identify differences in protein concentration between the extracted samples has indicated that there was no difference in terms of protein concentration between the healthy and diseased samples from the two different extraction methods. However, a t-test conducted on proteins quantified with the Bradford assay showed significant differences in terms of protein concentration between healthy and diseased samples with p-value is less than 0.05 (Table 5). This indicates that different quantity of protein was extracted from healthy and diseased roots of $P$. nigrum.

Meanwhile, a comparison of the two quantification methods resulted in an almost ten-fold difference in protein concentration. The BCA assay yielded higher protein concentration than the Bradford assay. A t-test was conducted to test if there was any statistical difference in protein concentration between the two methods. The p-value was 0.0000421 (Table 6), lower than 0.05 . Therefore, this value indicates a significant difference in the number of proteins between the two methods. The differences may be caused by the distinct sensitivities of the Bradford and BCA assays or due to interfering compounds that exist in the samples. ${ }^{15}$ The BCA assay is very sensitive towards interference from reducing sugars and lipids, which cause over-estimation of the protein concentration. ${ }^{14,21}$ Meanwhile, the Bradford assay is sensitive towards detergents, ampholytes and polyphenolics. ${ }^{22}$

\section{Relationships between quantification analysis and SDS-PAGE}

The phenol/SDS extraction method yielded only slightly higher protein concentration compared to the phenol method for both healthy and diseased roots. Nevertheless, statistical analysis showed there was no significant difference. From a previous study, the phenol/SDS extraction method had given maximised protein yields from olive leaves, displayed a good 2-DE resolution, and gave more spots with increased intensity, compared to the phenol method ${ }^{10}$. Furthermore, this method was faster than the phenol method, which is time-consuming. Qualitatively, the phenol/SDS extraction method gave sharper more distinct bands compared to the phenol extraction method. Thus, band 1 and band 2 in the diseased sample could be distinguished from the healthy sample using the phenol/SDS extraction method. This modified method of phenol/SDS extraction had been proven to be efficient, simple, economical and appropriate for proteomics studies with soybean roots, and likely apply to the root tissues of other plants. ${ }^{11}$ 
The protein concentration of the diseased sample was significantly higher than the healthy sample. Since the amount of starting materials and the amount of extracted protein samples loaded onto the SDS-PAGE gel was standardised, this could be attributed to the presence of the additional protein bands observed in the diseased sample. Although this study was based only on one-dimension gel analysis, distinct bands were observed, showing that proteomics differential expression can be performed based on SDS-PAGE as a preliminary study to discover plant responses to infections. Observation of the protein profile differences for healthy and diseased roots suggest that the distinct proteins in the diseased roots were induced as a response to infection or microbial activity surrounding the plant's roots..$^{22,23}$

\section{Differentially expressed proteins by MALDI- ToF/ToF MS}

Based on the analysis of differentially expressed proteins by MALDI-ToF/ToF mass spectrometry, results based on Mascot score of more than 46 indicates identity or extensive homology $(\mathrm{p}<0.05)$ for the analysed protein fragments. All Mascot scores for the Protein Band 1 are below 46, indicating close but not exact or matched identity to the identified proteins (Table 4). This is likely because P. nigrum proteins are not well represented in the database with only 241 hits on Uniprot (as of 12 September 2020). Nevertheless, for Protein Band 1, the peptide with the highest score of 44 matched a mannose-binding lectin (MBL) or agglutinin from Morus nigra. The size of this MBL was 161 amino acids, with a predicted molecular weight of $17 \mathrm{kDa}$. This matched quite closely to the estimated band size of the Protein Band 1, which was $\sim 20 \mathrm{kDa}$. The size differences are expected when comparing homologous proteins from different species. Furthermore, it has been reported that PR proteins from different plant genera showed similar but different mobilities during SDS-PAGE separation. ${ }^{24}$ From Table 4, the second-highest scoring peptide also matched an agglutinin isoform. Based on this, it is likely that the first differentially expressed protein is an MBL. Thus far, only two isoforms of MBLs have been identified in P. nigrum. ${ }^{25}$ In contrast, at least 49 lectins are belonging to the GNA (MBL) family in Arabidopsis thaliana. ${ }^{26}$ Therefore, there is a high possibility that the first differentially expressed protein is an MBL which has yet to be identified and sequenced.

MBLs or agglutinins belong to a family of mannose-binding proteins which are believed to recognise and bind high mannose type glycans in plant pathogens..$^{26,27}$ These lectins play an important role in plant defence signalling by recognising the specific glycans on pathogens during a pathogen attack. In the normal state, lectins are generally expressed at low levels but get induced to a higher level following a pathogenic attack or stress. ${ }^{28}$ This triggers the cell-wall defence response, such as the reinforcement of plant cell walls, produc- tion of antimicrobial metabolites and Pathogenesis Related (PR) proteins, and the plant hypersensitive response. ${ }^{28}$ There have been several reports of MBLs acting as PR proteins..$^{29-31}$ MBLs were overexpressed during infection of Capsicum annuum with a pathogen. ${ }^{28}$ Suppression of this gene led to increased susceptibility towards infection while overexpression of this MBL in Arabidopsis has been shown to increase plant resistance towards pathogens.

The study of plants using proteomic analysis has facilitated the discovery of PR proteins that act as a defence mechanism. ${ }^{5}$ Diseased plants usually synthesise a specific group of PR proteins which function as systemic acquired resistance. ${ }^{32}$ An induced infection study of $P$. nigrum leaves infected by Phytophthora showed that infected leaves expressed two additional proteins estimated at $16.5 \mathrm{kDa}$ and $8 \mathrm{kDa} .{ }^{5}$ In this artificial induction study, the relatively tolerant $P$. nigrum 'Kalluvally' variety showed delayed symptom development, where PR proteins were expressed after inoculation of Phytophthora. A study by Anh et al. ${ }^{33}$ reported similar findings with two overexpressed PR proteins of approximately 30 $\mathrm{kDa}$ and $<10 \mathrm{kDa}$, as well as overexpression of glucanase.

Analysis of Protein Band 2 resulted in low hit Mascot scores in the protein database (Table 4). The peptide with the highest score-matched and AAA-type ATPase family protein, as well as a hypothetical protein OsI_11535. The molecular size of the $12.5 \mathrm{kDa}$ protein in this study most closely matched the hypothetical protein OsI_11535 which was estimated to be $16.5 \mathrm{kDa}$. The difference in molecular weight between the two matches can be explained by a high possibility of the hypothetical protein being a fragment of the AAA-type ATPase family protein sequence. The hypothetical protein sequence matched the number 1 to 165 sequence of the AAA-type ATPase family protein sequence. Hence, it is predicted that the $12.5 \mathrm{kDa}$ differentially expressed protein was likely to be an AAA-type ATPase family PR protein.

An AAA-type ATPase protein has been reported as an additional novel mutant lesion mimic resembling (LMR) prediction gene in rice. LMR encodes this gene and enhanced resistance to rice blast and bacterial blight that is associated with the activation of two disease-related genes, PBZ1 and PR $1 .{ }^{34}$ In another study on putative pathogenesis-related gene expression, the protein was found to be likely involved in the necrotic stage of Rhizoctania solani pathogenesis along with pyruvate carboxylase (PC), glutathione-S-transferase (GLU) and major facilitator superfamily protein (MFS) ${ }^{35}$ With diverse functions, it is involved in detoxification of host efflux in multiple plant pathogenic fungi especially in defending the pathogen against reactive oxygen species..$^{36,37}$

Based on this preliminary study on differentially expressed proteins in normal and diseased pepper plants, the proteins expressed by the diseased roots in this study are likely to be PR proteins acting in response to pathogenesis. This suggests 
that PR proteins were also expressed by diseased $P$. nigrum when naturally infected. However, these proteins could differ from the ones expressed by leaves under artificial induction, because under natural conditions the roots interact with the soil microbiome and are also related to the disease affecting the plant.

\section{CONCLUSION}

In conclusion, the extraction of proteins from healthy and diseased roots of $P$. nigrum using the phenol/SDS extraction method yielded high-quality extraction where distinct protein bands could be observed between samples. The differentially expressed proteins bands, overexpressed in the diseased roots were identified through MALDI-ToF. However, due to the lack of database entries for P. nigrum, their identity could not be confirmed. Nevertheless, these proteins are likely to be PR proteins which could be used as invaluable markers for detection and management of plant pathogens. Furthermore, the induction of PR proteins before the infection could help plants gain resistance against disease. This, in turn, would help farmers to protect and improve the quality of the P. nigrum plants on their farm.

\section{ACKNOWLEDGEMENT}

Authors acknowledge the immense help received from the scholars whose articles are cited and included in references to this manuscript. The authors are also grateful to authors/ editors/publishers of all those articles, journals and books from where the literature for this article has been reviewed and discussed.

\section{Conflict of Interest}

Nil

\section{Source of Funding}

The authors thanked the Ministry of Education Malaysia for partial funding of this study via FRGS Grant FRGS/1611/2017, and Universiti Malaysia Sarawak for the F07(DPP38)/1256/2015(13) and the T\&L fund.

\section{Author's Contribution}

HH, AAH and SL designed the study. NEH and NFMC performed the experiments, and together with $\mathrm{HH}$ written the draft manuscript with input from all authors. AAH and SL helped to interpret the protein analysis data. All authors discussed the results and commented on the manuscript.

\section{REFERENCES}

1. Nelson SC, Cannon-Eger KT. Farm and Forestry Production and Marketing profile for Black pepper (Piper nigrum). In: Elevitch
CR, editor. Speciality Crops for Pacific Island Agroforestry: Permanent Agriculture Resources (PAR), Hōlualoa, Hawai' $i$ i, USA; 2011.

2. Ahmad N, Fazal H, Abbasi BH, Farooq S, Ali M, Khan MA. The biological role of Piper nigrum L.(Black pepper): A review. Asian Pac J Trop Biomed 2012;2(3):S1945-S53.

3. Srinivasan K. Black pepper and its pungent principle-piperine: a review of diverse physiological effects. Crit Rev Food Sci Nutr 2007;47(8):735-748.

4. Vishvnath G, Jain UK. Development of fingerprints for single component analysis of an ayurvedic formulation (Pippli churna) by high-performance liquid chromatography. Int J Curr Res Rev 2011;3(3):52-58.

5. Nazeem P, Achuthan C, Babu T, Parab G, Girija D, Keshavachandran R, et al. Expression of pathogenesis-related proteins in black pepper (Piper nigrum L.) about Phytophthora foot rot disease. J Trop Agric 2008;46(1/2):45-51.

6. Hussain H, Mustafa Kamal M, Al-Obaidi JR, Hamdin NE, Ngaini Z, Mohd-Yusuf Y. Proteomics of Sago Palm Towards Identifying Contributory Proteins in Stress-Tolerant Cultivar. Protein J 2020;39(1):62-72.

7. Jain PA, Kulkarni RD, Swamy BM, Mugeraya G, Srinikethan G, Sharanbasu KA. A method for efficient extraction of cell wall proteins from Candida albicans. Int J Curr Res Rev 2013;5(16):1-7.

8. Zeng GJ, Li CM, Zhang XZ, Han ZH, Yang FQ, Gao Y, et al. Differential proteomic analysis during the vegetative phase change and the floral transition in Malus Domestica. Dev Growth Differ 2010;52(7):635-644.

9. Ma R, Sun L, Chen X, Jiang R, Sun H, Zhao D. Proteomic changes in different growth periods of ginseng roots. Plant Physiol Biochem 2013;67:20-32.

10. Faurobert M, Pelpoir E, Chaïb J. Phenol Extraction of Proteins for Proteomic Studies of Recalcitrant Plant Tissues. In: Thiellement H, Zivy M, Damerval C, Méchin V, editors. Plant Proteomics: Methods and Protocols. Totowa, NJ: Humana Press; 2007. p. 9-14.

11. Rodrigues EP, Torres AR, Batista J, Huergo L, Hungria M. A simple, economical and reproducible protein extraction protocol for proteomics studies of soybean roots. Genet Mol Biol 2012;35(1):348-352.

12. Bradford MM. A rapid and sensitive method for the quantitation of microgram quantities of protein utilizing the principle of protein-dye binding. Anal Biochem 1976;72(1):248-254 .

13. Stoscheck C. Quantitation of protein. Methods Enzymol 1990;182:50.

14. Hussain H, Ngaini Z, Chong N. Modified bicinchoninic acid assay for accurate determination of variable length reducing sugars in carbohydrates. Int Food Res J 2018;25(6):2614-2619.

15. Lovrien R, Matulis D. Assays for Total Protein. Curr Protoc Protein Sci 1995;1(1):3.4.1-3.4.24.

16. Laemmli UK. Cleavage of structural proteins during the assembly of the head of bacteriophage T4. Nature 1970;227(5259):680685.

17. Shevchenko A, Tomas H, Havli J, Olsen JV, Mann M. In-gel digestion for mass spectrometric characterization of proteins and proteomes. Nat Protoc 2006;1(6):2856-2860.

18. Shevchenko A, Wilm M, Vorm O, Mann M. Mass Spectrometric Sequencing of Proteins from Silver-Stained Polyacrylamide Gels. Anal Chem 1996;68(5):850-858.

19. Perkins DN, Pappin DJC, Creasy DM, Cottrell JS. Probabilitybased protein identification by searching sequence databases using mass spectrometry data. Electrophoresis 1999;20(18):35513567. 
20. Wang W, Vignani R, Scali M, Cresti M. A universal and rapid protocol for protein extraction from recalcitrant plant tissues for proteomic analysis. Electrophoresis 2006;27(13):2782-2786.

21. Walker JM. The bicinchoninic acid (BCA) assay for protein quantitation. The protein protocols handbook. Totowa, NJ: Humana Press; 2009:11-15.

22. Kruger NJ. The Bradford method for protein quantitation. The protein protocols handbook. Totowa, NJ: Humana Press; 2009:17-24.

23. Zhang C-x, Tian Y, Cong P-h. Proteome analysis of pathogenresponsive proteins from apple leaves induced by the alternaria blotch Alternaria alternata. PLoS One 2015;10(6):e0122233.

24. van Loon LC, Gianinazzi S, White RF, Abu-Jawdah Y, Ahl P, Antoniw JF, et al. Electrophoretic and serological comparisons of pathogenesis-related (b) proteins from different plant species. Netherlands J Plant Pathol 1983;89(6):293-303.

25. Mahadevan C, Krishnan A, Saraswathy GG, Surendran A, Jaleel A, Sakuntala M. Transcriptome- Assisted Label-Free Quantitative Proteomics Analysis Reveals Novel Insights into Piper nigrum-Phytophthora capsici Phytopathosystem. Front Plant Sci 2016;7:785.

26. Ghahremani M, Tran H, Biglou SG, O'Gallagher B, She Y-M, Plaxton WC. A glycoform of the secreted purple acid phosphatase AtPAP26 co-purifies with a mannose-binding lectin (AtGAL1) upregulated by phosphate-starved Arabidopsis. Plant Cell Environ 2019;42(4):1139-1157.

27. Chen Z, Kai G, Liu X, Lin J, Sun X, Tang K. cDNA cloning and characterization of a mannose-binding lectin from Zingiber officinale Roscoe (ginger) rhizomes. J Biosci 2005;30(2):213-220.

28. Hwang IS, Hwang BK. The Pepper Mannose-Binding Lectin Gene $<$ em $>$ CaMBL $1</$ em $>$ Is Required to Regulate Cell Death and Defense Responses to Microbial Pathogens. Plant Physiol 2011;155(1):447-463.

29. Chow LP, Chiu LL, Khoo KH, Peng HJ, Yang SY, Huang SW, et al. Purification and structural analysis of the novel glycoprotein allergen Cyn d 24, a pathogenesis-related protein PR-1, from Bermuda grass pollen. FEBS J 2005;272(24):6218-6227.

30. Guidarelli M, Zoli L, Orlandini A, Bertolini P, Baraldi E. The mannose-binding lectin gene FaMBL1 is involved in the resistance of unripe strawberry fruits to Colletotrichum acutatum. Mol Plant Pathol 2014;15(8):832-840.

31. Ma QH, Tian B, Li YL. Overexpression of a wheat jasmonateregulated lectin increases pathogen resistance. Biochimie 2010;92(2):187-193.

32. Vandana V, Bhai RS. Differential expression of PR genes in response to Phytophthora capsici inoculation in resistant and susceptible black pepper (Piper nigrum L.) lines. Eur J Plant Pathol 2018;150(3):713-724.

33. Anh TT, Linh TB, Phong NV, Bien TLT, Tram T, Don L. Expression of proteins related to Phytophthora capsici tolerance in black pepper (Piper nigrum L.). Int J Agri Innov Res 2018;6(4):2319-2373.

34. Fekih R, Tamiru M, Kanzaki H, Abe A, Yoshida K, Kanzaki E, et al. The rice (Oryza sativa L.) LESION MIMIC RESEMBLING, which encodes an AAA-type ATPase, is implicated in defence response. Mol Genet Genom. 2015;290(2):611-622.

35. Rioux R, Manmathan H, Singh P, de los Reyes B, Jia Y, Tavantzis $\mathrm{S}$. Comparative analysis of putative pathogenesis-related gene expression in two Rhizoctonia solani pathosystems. Curr Genet 2011;57(6):391-408.

36. Imazaki A, Tanaka A, Harimoto Y, Yamamoto M, Akimitsu K, Park P, et al. Contribution of Peroxisomes to Secondary Metabolism and Pathogenicity in the Fungal Plant Pathogen Alternaria alternata. Eukaryotic Cell 2010;9(5):682-694.

37. Lopez-Huertas E, Charlton WL, Johnson B, Graham IA, Baker A. Stress induces peroxisome biogenesis genes. EMBO J 2000;19(24):6770-6777.

Table 1: Concentration of proteins extracted from the roots of $P$. nigrum using Bradford and BCA assays

\begin{tabular}{llcc}
$\begin{array}{l}\text { Type of } \\
\text { extraction }\end{array}$ & Condition of the roots & $\begin{array}{c}\text { Average protein concentration } \\
\text { using Bradford assay } \\
(\mathbf{m g} / \mathrm{ml})\end{array}$ & $\begin{array}{c}\text { Average protein concentration } \\
\text { using BCA assay } \\
(\mathbf{m g} / \mathbf{m l})\end{array}$ \\
\multirow{2}{*}{ Phenol } & Healthy roots P. nigrum & 0.849 & 16.916 \\
& Disease roots P. nigrum & 1.280 & 16.876 \\
\multirow{2}{*}{ Phenol/SDS } & Healthy roots P. nigrum & 1.311 & 20.298 \\
& Disease roots P. nigrum & 1.325 & 20.087 \\
\hline
\end{tabular}

Table 2: Analysis of variance of protein concentration using Bradford assay

\begin{tabular}{lcccccc} 
ANOVA & & & & & \\
Source of Variation & SS & df & MS & F & P-value & F crit \\
Between Groups & 0.471 & 3 & 0.157 & 2.175 & 0.168 & 4.066 \\
Within Groups & 0.577 & 8 & 0.072 & & & \\
Total & & & & & \\
\hline
\end{tabular}


Table 3: Analysis of variance of protein concentration using BCA assay

\begin{tabular}{lcccccc} 
ANOVA & \multicolumn{1}{c}{} & & & \\
Source of Variation & SS & df & MS & F & P-value & F crit \\
Between Groups & 32.669 & 3 & 10.889 & 0.742 & 0.556 & 4.066 \\
Within Groups & 117.292 & 8 & 14.661 & & & \\
Total & 149.961 & 11 & & & & \\
\hline
\end{tabular}

Table 4: Identification of predicted proteins

\begin{tabular}{|c|c|c|c|c|c|}
\hline No. & Fragment Sequence & Score & Accession no. & Protein ID & Molecular Size \\
\hline \multicolumn{6}{|c|}{ Protein Band 1} \\
\hline \multirow[t]{2}{*}{1.} & KTYGPYGK & 44 & AAL10685.1 & $\begin{array}{l}\text { mannose-binding lectin } \\
\text { [Morus nigra] }\end{array}$ & $17 \mathrm{kDa}$ \\
\hline & & & XP_024018763.1 & $\begin{array}{l}\text { agglutinin alpha chain } \\
\text { [Morus notabilis] }\end{array}$ & $17 \mathrm{kDa}$ \\
\hline 2. & SGAYLDAIGVHMEYF & 30 & $\mathrm{ABC}_{70328.1}$ & agglutinin isoform [Castanea crenata] & $31 \mathrm{kDa}$ \\
\hline \multicolumn{6}{|c|}{ Protein Band 2} \\
\hline \multirow[t]{2}{*}{1.} & AVAVEVDSGK & 20 & ABF95891.1 & $\begin{array}{l}\text { AAA-type ATPase family protein, puta- } \\
\text { tive, expressed } \\
\text { [Oryza sativa Japonica Group] }\end{array}$ & $110 \mathrm{kDa}$ \\
\hline & & & EAY89974.1 & $\begin{array}{l}\text { hypothetical protein OsI_11535 } \\
\text { [Oryza sativa Indica Group] }\end{array}$ & $16.5 \mathrm{kDa}$ \\
\hline
\end{tabular}

Table 5: t-test between healthy and diseased samples assuming two equal variances from Bradford assays

\begin{tabular}{lcc} 
& Variable 1 & Variable 2 \\
Mean & 0.849 & 1.280 \\
Variance & 0.0085 & 0.0799 \\
Observations & 3 & 3 \\
Pooled Variance & 0.044 & \\
Hypothesized Mean Difference & 0 & \\
df & 4 & \\
t Stat & -2.505 & \\
P(T<=t) one-tail & 0.033 & \\
t Critical one-tail & 2.131 & \\
$\mathrm{P}(\mathrm{T}<=\mathrm{t})$ two-tail & 0.066 & \\
$\mathrm{t}$ Critical two-tail & 2.776 & \\
\hline
\end{tabular}

Table 6: t-test for Bradford assays and BCA assays using two samples assuming two equal variances

\begin{tabular}{lcc} 
& Variable 1 & Variable 2 \\
Mean & 1.325 & 16.876 \\
Variance & 0.04 & 2.712 \\
Observations & 3 & 3 \\
Pooled Variance & 1.376 & \\
Hypothesized Mean Difference & 0 & \\
df & 4 & \\
t Stat & -16.236 & \\
$\mathrm{P}(\mathrm{T}<=\mathrm{t})$ one-tail & 0.0000421 & \\
$\mathrm{t}$ Critical one-tail & 2.131 & \\
$\mathrm{P}(\mathrm{T}<=\mathrm{t})$ two-tail & 0.0000842 & \\
$\mathrm{t}$ Critical two-tail & 2.776 & \\
\hline
\end{tabular}




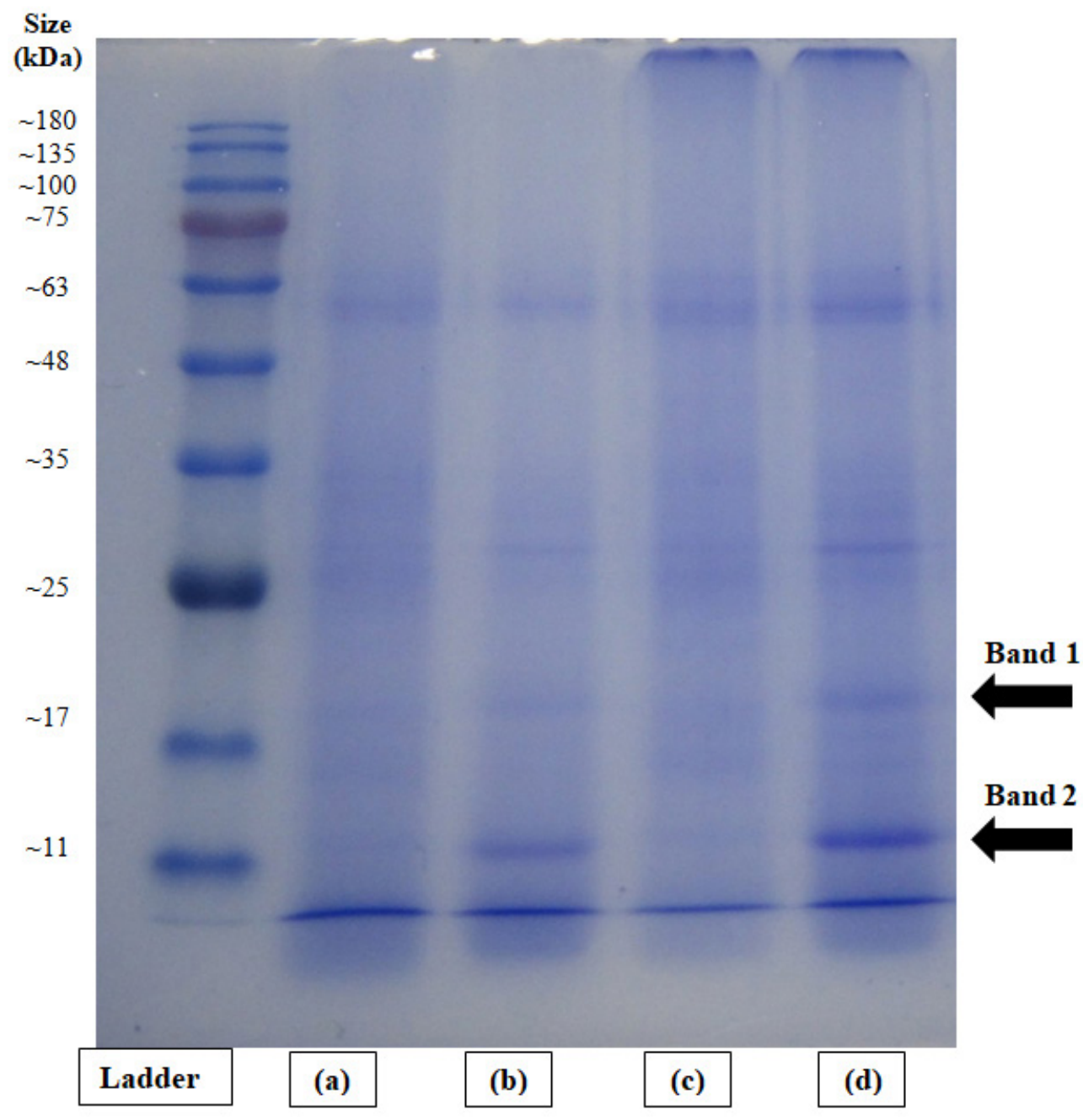

Figure 1: Band separation of proteins extracts, $(1 \mathrm{mg} / \mathrm{mL}$ ) by SDS-PAGE using Coomassie Brilliant Blue R (CBB-R) staining. (a) Phenol extraction method- Healthy roots of $P$. nigrum (b) Phenol extraction method- Diseased roots of $P$. nigrum (c) Phenol/SDS extraction method- Healthy roots of $P$. nigrum (d) Phenol/SDS extraction method- Diseased roots of $P$. nigrum. The molecular weight of the protein standard as indicated on the left. 